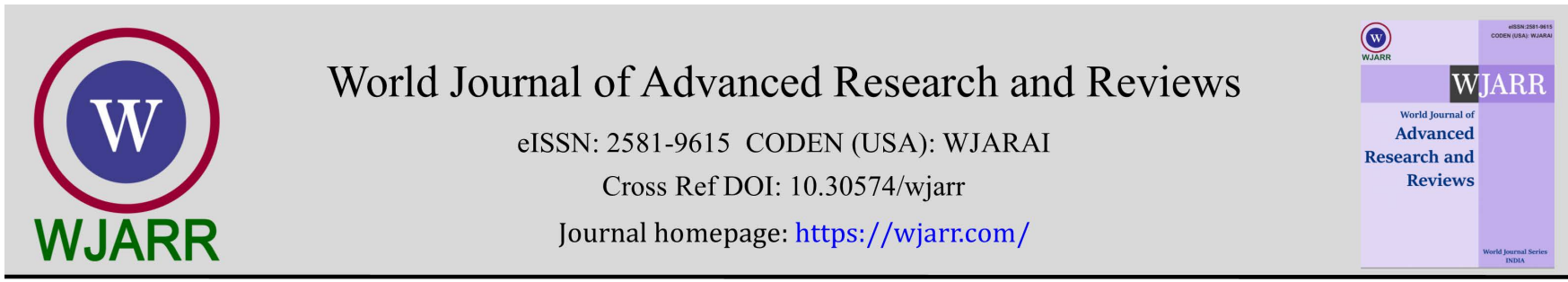

(REVIEW ARTICLE)

\title{
Prohibition for a better life in the future local knowledge of Negeri Besar village South Sorong Regency
}

\author{
Hendrik Arwam 1, ${ }^{*}$, Andoyo Supriantono ${ }^{2}$, Yolanda Holle ${ }^{2}$ and Yusuf W. Sawaki ${ }^{2}$ \\ ${ }^{1}$ Environmental sciences programs of Papua University, Jl. Gunung Salju Amban, 98314, Manokwari, West Papua \\ Province, Indonesia. \\ 2 Postgraduate programs of Papua University, Manokwari, West Papua Province, Indonesia.
}

World Journal of Advanced Research and Reviews, 2021, 10(03), 077-084

Publication history: Received on 18 April 2021; revised on 18 May 2021; accepted on 21 May 2021

Article DOI: https://doi.org/10.30574/wjarr.2021.10.3.0177

\begin{abstract}
The aim of the research to know the local wisdom and knowledge of the people in Negeri Besar (Nebes) village, who have long used the sago forest since the time of their ancestors Kokoda district. This is a proof that the society is capable of building its civilization and culture. The people of Nebes Village are able to manage the sago forests collectively. This is a proof that the society is capable of building its civilization and culture. Even though the community lacks in terms of technology, it is able to change the pattern of sago forest cultivation to become more orderly. Furthermore, the facts show that what the people of Nebes village have, are more than the things that have been stated above.
\end{abstract}

Keywords: Prohibition; Local Knowledge; Community; South Sorong Regency

\section{Introduction}

Current development is a powerful weapon in driving social changes in the society. The various forms of development have long entered the territory of indigenous peoples in West Papua. The development (vision, theory, and process) that has penetrated rural areas has various implications. Initially, viewed from a development perspective, everything related to local culture was considered an obstacle in the development process. It was at the beginning of the 21 st century that these traditional communities started to get attention, as well as the emergence of movements against the marginalization of local culture.

The spirit against cultural marginalization is manifested in the cultural discourse. At first, it was just a reflection, but now cultural discourse is no longer using the question word "what" culture is, but rather "how" the cultural phenomenon is being discussed and "for what/whose sake" the discourses are built [1].

The marginalization and exclusion of a society and its culture can be found in the cultivation of sago forests in South Sorong district, West Papua Province. It is located in the southern part of the Bird's head peninsula, in which, a part of the South Sorong regency is on the coastal area, bordered to the Arafura Sea. In South Soromg regency, there are 8 districts that have the potency for sago palm cultivation. Based on the data, South Sorongregency has an area of 694,221 ha-1 with $311,591 \mathrm{ha}^{-1}$ or $44.8 \%$ of which is sago forest [2].

Kais district in South Sorong Regency has the largest area of sago forest [2]. The potency of sago palm in Kais district is estimated to yield 7.6 tonnes per ha. It is lower than the yield of sago palms in other parts of Indonesia, such as Meranti regency in Riau, that yields 15 tonnes per ha. Likewise, the Kokoda district yield 9.7 tonnes per ha, with a smaller area of sago palm compared to the Kais district. The reasons why the yield of sago palm in South Sorong Regency is less

${ }^{*}$ Corresponding author: arwamhendrik79@gmail.com 
optimal, it is due to the differences in climate, soil fertility, and inundation rates. In addition, the process of sago starch extraction so far has not been effective and efficient, due to the fact that the farmers in this the area still use conventional method.

This condition illustrates the lack of respect for local culture and knowledge. The Kaiso way of life - in terms of production and consumption systems - is considered backward, because the people still do not recognize plant cultivation [2]. However, according to Dove in [3], without cultivated plants, there is no discipline of individual land tenure, nor intensification of labor by family members.

In general, the picture of the optimum use of sago palm cultivation can be looked at from a modern point of view, such as the development of sago processing business that aims to produce sago starch based on the criteria of efficiency, effectiveness, quality, and flexibility [2]. However, it raises the question, whether the proposed solutions in terms of the development of sago palm cultivation and management would be able to accommodate the various aspects of people's lives, or is it just trying to understand the reality by explaining our understanding, as it is said by Popper that theory is not the same with reality. Furthermore, it seems that we tend to apply a number of rules and regulations to reality, all of which are our cognitive efforts to make the reality understandable and explainable. These efforts are attempts to change the reality of a society condition based on our viewpoints and justification that we believe to be true.

In the name of development for the welfare of the community, land conversion was carried out, and companies began to operate. The main purpose is to create jobs. In reality, those activities seems to only improve the standard of living indicators. In relation to that case, the writers agree with the statement of Firdaus RSM [4], who stated that the presence of private parties in the Sago processing industry arises due to the assumption that the traditional method of sago palm cultivation by the indigenous peoples has not been optimum, and are not able to maximize the existing potency.

The existence of companies in the sago palm processing industry may cause problems to the community. That people's lives have become increasingly distant from the food sources, such as sago harvesting and hunting of animals in sago forests [3]. Such a case has happened in Sidey District, Manokwari Regency. When the oil palm company operated in the area, some residents complained about the distance that had to be traveled from their homes to their gardens that were getting further away. At first glance, it seems like a paradox, on the one hand they accept the company to operate, but on the other hand they complain about their lives due to the existence of the company.

If so, what actions need to be taken so that problems like the above can be avoided? The offers of solution such as economic democracy have been given, to manage the sago forests in Kais district [4]. However, for the writers, we have observed that the potency that comes from the indigenous peoples themselves is also an alternative, and that is the main topic of this paper.

The potency that the writers mean is the local wisdom and knowledge of the people in Negeri Besar (Nebes) village, Kokoda district, who have long used the sago forest since the time of their ancestors. Nebes village in Kokoda district is part of 5 Districts, along with Kais district which is located on the coastal area of South Sorong Regency. During the dry season at the end of 2020, the Indigenous Peoples Organization (LMA) Emeyode Kokoda reminded the residents not to burn the forest along the river from Tarof to Nebes. At first glance, it seems that the activities carried out by LMA are intended to prevent forest fires, in fact it actually has its own history for the local community.

The same is the case with the concept of sago management. One of the informants, Mr. Lukman Ugaje, said that he had attended a comparative study in Bengkalis to see how the process of sago palm cultivation there. However, according to him, the activities carried out there are not in accordance with the mindset of the Kokoda community in terms of the way of cultivating the sago palm. Based on the condition above, the writers make an attempt to raise the issue of local wisdom and knowledge of the Nebes village community in Kokoda district by directly listening to the voices of indigenous peoples. For the writers, the results of this study, would become an evidence of the existence of the indigenous peoples who have their own civilization in the midst of the developments and globalization that carry a single truth

\section{Material and methods}

The method applied in this study is a descriptive method, by using observation and interview techniques. The application of this method is carried out based on the phenomena by prioritizing the subjectivity aspects of the informants, namely the local people in their daily lives. It is important because experiences are the result of everyday life. The goal is to get a picture of the values of human life. These human values are part of the life that is lived, held firmly and maintained. In other words, the truth of subjectivity is real experiences [5]. 
In phenomenology, humans are the source of knowledge. Humans are the creators of their history. Humans are the people who construct a "world view and their world" or Weltanchauung [6]. For this reason, by writing about life experiences and local wisdom of the people in Nebes Village, the writers believe that the writers are building the world and people's knowledge, as the actors who play a role in it

\section{Results and discussion}

The real threat of land tenure by the State and companies in the coastal area of South Sorong Regency is the further distance from the village to the community food sources, as Larastiti wrote in his article ("social reproductive crisis in the Kaiso Community, Kais district"). However, long before that, the people of NegeriBesar village (Nebes) in Kokoda District, had experienced these challenges, and internally made a collective agreement, so that the community could still reach their food sources easily.

The village of Negeri Besar (Nebes) is located in Kokoda District, one of five districts in the coastal area of South Sorong Regency. In Kokoda language, Negeri Besar means "Maretinani". The natural environment in the Kokoda district is similar to that of the Kais district, consisting of peat swamps fulled of sago palms. According to Haryanto B et.al., [2], the area of sago palm forest in Kokoda district is 61.3 thousand ha, the second largest after Kais district. The Nebes village is in the middle of a large swamp, in the northern part of the capital city of Kokoda district, about $10 \mathrm{~km}$ away. Based on the results of the interview, it is known that the name Kokoda is derived from the name of the place where the community lives. In the past, their ancestors gave the name Kokoda based on the characteristics of the habiat which is consisted of large swamps fulled of mat grasslands and sago palm forests.

The administrative territory of Nebes village is adjacent to four other villages, namely Topdan, Migirito, Daobak, and Nayakore. In the past, there was only one village, namely NegeriBesar as the main village. Along with the increasing number of the population and government administration, it was then followed by the division of the village. There is only one clan that inhabits the village of Nebes, namely the Ugaje clan. According to the results of the interview, it became known that the Ugaje clan is the name of the ancestors of the community who first came and lived in the area.

To get to the Nebes Village can be done on foot or by boat. The choice of means of transportation to be used is very dependent on the natural conditions (rainy/summer/dry). During the long dry season in 2015, some residents said that for several months the community had to transport the rice aid from the government by carrying it on their shoulders to NegeriBesar Village on foot, because the river that was usually used to pass by boat had become dry.

The people of Nebes Village make ends meet by utilizing the characteristics of the natural environment in which they live. The people in this village know that the natural environment in the area consists of two main seasons, namely the rainy season (Taikinani) and the dry season (Managaya). This characteristic is well understood by the local community because their residence (Nebes village) is located along the Kiawage River. The main characteristic is the volume of water, if the volume of water is very large, the village community understands it as the rainy season. However, if the volume of water is very small, only in the form of water flow as high as an ankle, the local people understand it as the dry season. Likewise, the term that refers to a river, at certain times it is referred to as a river, but at other times the river is referred to as a river flow. It is due to fact that the water flowing in the river (during the rainy season) is not the water that comes from certain springs, but rather rainwater that flows from the northern part of North Kokoda district to the south, through Nebes Village.

According to respondents, this river will be formed during the rainy season, which occurs between October and February. This rainy season is often referred to as flood by the community, to describe the river area which is flowed by water, a situation that is different from the situation during the dry season, when the river will dry up and leave only heel-high water flow.

During the rainy season, the activities of the community become easier, because they can reach the village by boat. In addition, the rainwater in the river made it easier for them to carry the sago stalks from the sago hamlet to their village by using a raft, then extracting it. In addition, the presence of water in the river also makes it easier for them to extract thefibrous residue, crushed and kneaded, to release the starch, both while in the sago hamlet and in the village. This is very different from the situation during the dry season, when the rivers and streams began to dry up, the people of Nebes Village, who basically lived on the riverbank, have to travel long distances on foot to reach the sago hamlet. It was considered too far and tiring whem they have to walk on foot, especially if they have to carry the stalks or freshly kneaded sago flour on the shoulders. As a result, the community had to spend more energy and take more time to reach the sago hamlet. 
Table 1. Community Knowledge of Sago Palm

\begin{tabular}{|c|c|c|}
\hline Part & $\begin{array}{l}\text { Kokoda } \\
\text { Language }\end{array}$ & Uses \\
\hline Suckers/pups & Emegomo & \\
\hline $\begin{array}{l}\text { Sago palm } 2-4 \\
\text { meters in height }\end{array}$ & Ketabi & \\
\hline Sago Palm & Como & \\
\hline Athornless sago palm & Wawo & \\
\hline Trunk & & $\begin{array}{l}\text { The bark of the lower part of the trunk near the roots is used as a } \\
\text { material for the wall of houses and bridges }\end{array}$ \\
\hline Bark & Nat CDV & $\begin{array}{l}\text { The bark of the upper sago trunk is used as a container for squeezing } \\
\text { the starch }\end{array}$ \\
\hline Midrib & Fauw & $\begin{array}{l}\text { Midrib is combined with coconut fibers (nuruto) that is attached to } \\
\text { the midrib using a sago stick. It function as a filte, which is made of } \\
\text { wooden supports (Uradi), and is used as a container to squeeze sago } \\
\text { (edemetoni). When the sago fibers is squeezed in this container, the } \\
\text { sago water will flow into a container known as "Bau", which is made } \\
\text { of thick sago stem bark. Currently, the villagers usually use oats as a } \\
\text { container for sago water. }\end{array}$ \\
\hline Chopper tool/Nani & Као & \\
\hline Leaf & $\begin{array}{l}1 \text { sheet : kanani } \\
1 \text { midrib : kawoye }\end{array}$ & House roof, grass cloth, noken. \\
\hline $\begin{array}{l}\text { Young shoots } \\
\text { (still wrapped) }\end{array}$ & Kani & Vegetables to be eaten \\
\hline $\begin{array}{l}\text { Young shoots (already } \\
\text { out/up, but it is still } \\
\text { closed) }\end{array}$ & Kukuri & \\
\hline $\begin{array}{l}\text { Young shoots (already } \\
\text { out/rising and the } \\
\text { leaves are already } \\
\text { opened) }\end{array}$ & Opweti & $\begin{array}{l}\text { It is used as a base for grass cloth (traditional Emeyode clothing). In } \\
\text { this condition, the sago palm (is having opweti) is ready to be ct down. } \\
\text { The people call it metuado }\end{array}$ \\
\hline Horn is out & Metokun & \\
\hline Bearing fruit & Tagera & Sago fruit is edible \\
\hline $\begin{array}{l}\text { The contents that are } \\
\text { still inside the sago } \\
\text { stem }\end{array}$ & Kabuni & \\
\hline $\begin{array}{l}\text { Contents (has been } \\
\text { extracted into starch }\end{array}$ & Apota & \\
\hline Sago starch & Kopia & $\begin{array}{l}\text { As a food: staple food for everyday life. } \\
\text { It is also served as a meal to eat together (if a family has an } \\
\text { accident/hand cut, a banquet is held so that the family unity remains } \\
\text { strong, especialy those who are living together in Negeriesar. } \\
\text { Served as a food for the relatives or friens who stop y or on trips. } \\
\text { For health: } 1 \text { cup of sago, which is freshly burned, stirred, and being } \\
\text { given to children who experienced the symptoms of sarampa. }\end{array}$ \\
\hline
\end{tabular}




\begin{tabular}{|c|c|c|}
\hline $\begin{array}{l}\text { Sago porridge (glue } \\
\text { like paste) }\end{array}$ & Irai & \\
\hline Rolled into balls & Irau & $\begin{array}{l}\text { Served at a certain events, or served as a dishes for the quests who } \\
\text { come to the village }\end{array}$ \\
\hline Dry sago & $\mathrm{Ti}$ & \\
\hline Burned sago balls & Kopueti & \\
\hline Roasted sago leaves & Kari-kari & \\
\hline Sago bag & Tabara & \\
\hline Short Tomang sago & Peyate & \multirow[t]{2}{*}{ The villagers sell it to Tarof, as well as to Teminabuan and Kokas. } \\
\hline LomgTomang sago & Tuburi & \\
\hline
\end{tabular}

Another thing that needs to be questioned is why during the difficult conditions in the dry season, sago remains the choice of the people of Nebes village. The reason is that, the need of the people of Nebes village for sago is not one aspect only, as a staple food. Sago palm has also become the source of life for the people of Nebes village. The following is a description of the knowledge of the Nebes village community about sago palms and their uses which is stored in the Kokoda language based on the results of interviews.

Apart from the richness of the language and the usefulness of sago in the life of the Kokoda community, there are also several other functions of the sago palm tree, especially the trunk of the sago tree. When they are trying to cut down a sago tree, the villagers will usually first check whether the sago tree can be cut or not. The process is to cut a part of the sago tree trunk, then take the contents (Kabuni). The contents are then being eaten by chewing so that it become thin. After being runny, the chewed contents are then rubbed on the body and left it for a while. If the chewed water leaves white marks on the body, the sago palm tree is then considered ready to be cut down. If not, then they have to find another sago palm tree.

After the sago palm tree has been cut down, the next step is to find out which part of the sago trunk that contains good sago content. It is done by peeling or removing the bark of the sago palm trunk. If the contents is runny, that portion will be left out. The part of the sago trunk that contains a lot of water is usually close to the roots. According to Mr. NatanielUgaje, when splitting the sago palm trunk, the process usually starts from the part close to the midrib to the roots.

However, it does not mean that the remaining part of the sago trunk is considered completely non-functional. The sago trunk or stems will be left for several weeks as a breeding ground for sago worms (Apatar). After that, the sago worms that develop on the rotting sago stems are ready to be harvested. In addition, the remaining sago stems can also be used as a hunting ground or used as a wild boar trap. This hunting activity is carried out at night, when the sago stalks are rotten, the contents will become food for wild boars. The pig will eat the contents of the sago stem until it enters the inside of the sago stem. This condition will make wild boar being trapped in the sago trunk, and the hunters will immediately spear it.

The existence and uses of sago in the community life in Nebes Village has been explained above. The challenges of the natural environment which has two seasons often make it difficult for the villagers to do their activities. This clearly adds to the knowledge of the Nebes village community which is not only limited to the efficient use of sago palm, but the community also becomes motivated to try to manage sago palm forests so that they can interact with their food sources. This process can be seen from the way they manage the sago tree which previously only used it, namely as a source of food and complement to their daily needs, becoming aware of the importance of the efforts to maintain and manage the sago palm forest. The goal is simple, so that people can still easily access the food sources.

The people of Nebes Village are very familiar with the term Ogomo (which means prohibition). This prohibition was conveyed by their parents, and even since their ancestors to their descendants (read: children and grandchildren) who used or utilized the sago palm forest in their hamlet. This ogomois in the form of prohibitions for the community to take kani (young sago palm), especially on small sago palms (Ketabi: 2-4 meter height of sago tree), on the riverbank. This prohibition also applies to people who want to take Kanion a sago palm tree close to the village. This prohibition is enforced because when people take kani from small sago palms (ketabi) by cutting down the sago palm trees, the action is considered inefficient. The shoots of Kanishould be taken simultaneously by cutting the sago palm tree, then 
processing it altogether.An alternative is to take Kani leaves deep down in the forest. The results of the interviews indicated that when small groups went looking for Kani in the forest, they usually could not hear the calls or voices from the other groups when they called each other because they were far apart. This prohibition is enforced so that when the dry season arrives, people do not have to bother looking for sago palm trees to be harvested deep into the forest, usually up to 2-3 kilometers from the riverbank.

This prohibition arises in accordance to the various considerations in the lives of the parents and ancestors. The results of the interviews indicated that this prohibition was based on the "calculations" made by the ancestors and the parents in order to live better in the future. It is closely related to the community's habit of extracting sago starch, which is often practiced by nuclear families and close relatives (between 5 and 10 people). And if the husbands are travelling, then the activity of extracting sago starch is carried out by the mothers and their children.

Apart from the prohibition, there is also a recommendation for replanting sago palm trees. In the past, there were only wild trees on the banks of the river, but now sago trees are begins to grow on the river banks of the Kenaburi and Kiawage rivers, which are sago trees planted by the community. According to the community, instead of cutting down and bringing the sago to the village, it is better to plant sago palms on the banks of the river so that all activities can be carried out in the same place starting from cutting down, , split out, extracting, to kneading in water to releases the starch. There are also people who plant sago palms near their houses in Nebes village.

Actually, the correct term is not planting, because people only eat the fruit of the sago palm tree, then throw the seeds in an empty place so that it can grow. However, over time, these places have been determined by the community, such as riverbanks and yards around the house. This is very reasonable so that people do not have to go too far places to harvest sago palm when the dry season arrives.

Two concepts of sago palm management for the Nebes community, namely the concept of community awareness to plant sago and the concept of prohibiting harvesting of Kani, complement each other, in order to face the challenges of current natural conditions. Although the growth of sago palm trees takes a long time, ranging from 15 to 20 years, what the community does is in accordance to what their parents and ancestors said (to live for a better life in the future).

Basically, human adjustment to the environment can be done in two ways, namely by changing human behavior, or changing the natural environment around it (Hardesty in [5]). Based on the perspective of environmental psychology, the same thing was stated, that there are two types of adaptive behavior [7]. First, by changing the behavior to suit the environment and secondly by changing the environment to suit the behavior. The first is called adaptation, and the second is called adjustment. It can be seen here that people do not change the environment in which they live, but rather change their behavior to suit the natural conditions in which they live. Even in the absence of modern technological equipment, are able to build a better society.

The adjustment of humans to the environment is closely related to the need to meet their needs, especially to meet the need for food. For this reason, the use of sago palm by the community shows that sago palm is the core of its culture. It was also stated by Steward who emphasized how resources are managed. In other words, the production pattern of people's needs is at the core of culture [5]. Therefore, there are three things that will be discussed in this study.

The first is about the interaction between the people of Nebes village and their sago forest. These interactions have defined the picture of the world and how people treat the world (where they live). This assumption follows the opinion of [1] who stated that all social responses (positive in the form of cooperation, negative in the form of conflict) are initially driven by the need to respond to nature. What is mostly produced by humans, was originally a human response to nature to meet their daily needs.

The mindset and work patterns of the Nebes villagers are formed based on their relationship when they are processing the sago palm into starch. After checking the sago palm trees that can be cut down (local term: Metuado) or (modern term: Masak Tebang / MT), the community will cut the sago palm tree down. When they want to take the contents or starch-containing pith (kabuni)of the sagopalm, the community takes the contents starting from the softest part of the sago palm trunk. For the people of Nebes Village, the easiest part to take is the part of the sago stem that is close to the midrib, then leaves the contents of the hard sago stem near the root to be taken last. This method of working forms the world view that everything should be done from the easiest. It can be seen clearly from the prohibition (Ogomo) and the awareness of the people of Nebes Village to plant sago.

The "easy" mindset that is formed makes people accustomed to taking Kani on sago palms along the river, or around the village, but because the sago palm trunk are still small (Ketabi), it cannot be used optimally, such as producing sago 
starch or other sago palm products. Often this habits then makes it difficult for the other community members who want to find sago palms to be extracted, especially during the dry season, because they have to go far away and require a lot of energy, causing an impression in the mind that it is difficult. In this context, awareness emerged to manage the sago hamlet by limiting the activities of harvesting Kani, so that later it was "easy" to harvest sago. "Easy" means the sago tree they are looking for is not far from the riverbank or from the village location.

It can be said that in this case there has been a shift in instinct from natural instinct to cultural instinct. The people of Nebes village, who are usually accustomed to using sago palm until it runs out, are starting to have the awareness to be able to jointly manage sago palm through deliberations. At least it can be said that human history is a process, in which humans as subjects, train their ability to make choices for humans as objects (along with other objects).

Second; the awareness of the Nebes villagers to maintain the relationship with their ancestors. States that the loss of relations with the land (ancestors) has enormous implications for one's understanding of his historical and ethnographic existence [6]. People lose understanding to the fact of their origin. This is what is currently being maintained by the people of Nebes Village so that the community does not lose their current life relationship with their parents and ancestors. Starting from the clan name (Ugaje) which is the name of their ancestor shows that the local community still maintains their relationship with their ancestors. Following are the prohibition conveyed by their parents and ancestors. This prohibition signifies the relationship between people living today and their parents and ancestors, as well as the land on which they live. As a living community, they really understand clearly of the marked customary ownership, where several areas of the sago hamlet have their names written on them. Thus, caring for sago palm is a manifestation of efforts to carry out prohibitions and messages from parents as a form of friendship, as well as to keep the series of life that has been arranged between him and nature since his ancestors can run well.

Based on the prohibition that exists in the Nebes community, it can be raised and introduced into local wisdom or customary law. This is because the prohibition in question is agreed upon by all members of the clan and becomes a guide for them in managing the sago hamlet. This prohibition becomes a common property for society as the main characteristic of culture. Furthermore L. Pospisil expressed his opinion about customary law, that law is an activity within the framework of a culture that has a social control function [7]. In this case, the prohibition (Ugomo) passed on by the parents and ancestors to the descendants has been implemented up to now. If it is too far away, then this can be called the norm or local wisdom of the Nebes community in the sago forest organization.

\section{Conclusion}

The people of Nebes Village are able to manage the sago forests collectively. This is a proof that the society is capable of building its civilization and culture. Even though the community lacks in terms of technology, it is able to change the pattern of sago forest cultivation to become more orderly. Furthermore, the facts show that what the people of Nebes village have, are more than the things that have been stated above. The economic style is a response or adjustment to the natural environment which is also complex. People also don't spend much of their time, just eating from day to day. The reality shows that people with high efficiency, working only a few hours each day, can live with a lot of free time.There is public awareness to get out of their limitations, but still respect the others and the natural environment.Communities altogether are able to overcome biological limitations by making boundaries, so that their lives remain easy to live by. We hope that the government as the main actor of development may afford the community in utilizingand managing the potency of the people of Nebes village. Not only just realizing and acknowledging, but also helping them to make a change in their life into a better life

\section{Compliance with ethical standards}

\section{Acknowledgments}

The author's gratitude goes to the Head and Secretary of Negeri Besar village (Mr. Nataniel Ugaje and Mr. Yohanis Ugaje). Also, to Mr. Lukman Ugaje who is busy as a supervisor in Kokoda district, yet still have time in supporting us in doing the research.

\section{Disclosure of conflict of interest}

The authors declare no conflict of interest regarding the publication of this paper. 


\section{Statement of informed consent}

Informed consent was obtained from all individual participants included in the study.

\section{References}

[1] Kusumohamidjojo B, Jamilah S. (2009). Filsafat Kebudayaan: Proses Realisasi Manusia. Bandung, Jalasutra

[2] Haryanto B, Mubekti, Putranto A.T. (2015). Potential and Utilization of Sago Starch to Support Food Security in South Sorong Regency, West Papua. Jurnal Pangan, 24: 97-106.

[3] Larastiti C. (2020). Sagu dan Krisis Reproduksi Sosial Orang Kaiso. Wacana: Jurnal Transformasi Sosial. Wacana: 38: 103-132.

[4] Firdaus RSM, Wibowo IA (2020). Demokrasi Ekonomi dan Industri Rakyat: Tawaran Jalan bagi Industri Sagu oleh Masyarakat Adat di Sorong Selatan, Papua Barat. Wacana: Jurnal Transformasi Sosial. Nomor. 2020; 38: 133-170.

[5] Farid M, Adid M, Main A, Setyowati N Rr, Siahaan S, Jatiningsih O, Rusmanto J, Muwaffiqillah, (2018). Fenomenologi Dalam Penelitian Ilmu Sosial. Jakarta: Prenadamedia Group.

[6] Abdoellah O. S. (2020). Dari Ekologi Manusia Ke Ekologi Politik. Jakarta: Gramedia Pustaka Utama.

[7] Jenkins A (1979). The Social Theory of Claude Levi- Strauss. The Macmillan Press Ltd, London. 